\title{
Heilsa og lifun íbúa fyrir og eftir setningu strangari skilyrða fyrir flutningi á hjúkrunarheimili 2007
}

\author{
Ingibjörg Hjaltadóttir ${ }^{1,2}$ hjúkrunarfræðingur \\ Kjartan Ólafsson ${ }^{3}$ félagsfræðingur
}

Árún K. Sigurðardóttir ${ }^{4,5}$ hjúkrunarfræðingur

Ragnheiður Harpa Arnardóttir ${ }^{4,6,7}$ sjúkrapjálfari

\begin{abstract}
${ }^{1}$ Hjúkrunarfræðideild Háskóla Íslands, flæðisviði Landspítala, ${ }^{3}$ hugog félagsvísindasviði Háskólans á Akureyri, ${ }^{4}$ heilbrigðisvísindasviði Háskólans á Akureyri, ${ }^{5}$ deild mennta og vísinda á Sjúkrahúsinu á Akureyri, ${ }^{6}$ endurhæfingardeild Sjúkrahússins á Akureyri, ${ }^{7}$ lungna-, ofnæmis- og svefnrannsóknasviði læknavísindadeildar Uppsalaháskóla, Svípjóð.
\end{abstract}

Fyrirspurnum svarar Ingibjörg Hjaltadóttir, ingihj@hi.is

\section{Inngangur}

Eftir pví sem hlutfall eldra fólks eykst á Íslandi má búast við breyttum pörfum samfélagsins fyrir heilbrigðispjónustu. Pegar heilsufar og færni einstaklinga skerðist verulega getur sólarhringspjónusta á stofnun verið nauðsynleg. Íbúar hjúkrunarheimila lifa pannig nær undantekningarlaust við verulegan heilsubrest ${ }^{1,2}$ og íslensk hjúkrunarheimili eru par engin undantekning. ${ }^{3}$

Samanburður á dvalartíma einstaklinga sem flytja inn á hjúkrunarheimili (dvalartími fram að andláti) er flókinn vegna mismunandi viðmiðunartíma sem notaður er í rannsóknum. Í rannsókn Kelly og félaga (2010) á íbúum á bandarískum hjúkrunarheimilum ( $\mathrm{n}=43.510)$ höfðu 53\% íbúanna látist innan 6 mánaða, ${ }^{4}$ en í nokkrum árum eldri bandarískri rannsókn voru 23\% íbúa látin eftir 6 mánuði. ${ }^{5}$ Í íslenskri rannsókn höfðu 28,8\% látist innan árs frá komu. ${ }^{6}$ Rannsókn frá Hong Kong (n=1860) sýndi að eftir 5 ár voru $54,2 \%$ íbúa látin. ${ }^{1}$

Fjölmargir pættir hafa áhrif á lifun inni á hjúkrunarheimilum. Rannsóknir hafa sýnt að spápættir fyrir lifun inni á hjúkrunarheimilum eru meðal annars kyn, aldur, heilabilun, ${ }^{7}$ færni við athafnir daglegs lífs (ADL), stöðugleiki heilsu, ${ }^{1}$ hvaðan íbúi kom (að heiman eða frá spítala), færni til félagslegrar pátttöku ${ }^{6}$ og vannæring. $^{2}$

Mat á færni og pörf fyrir pjónustu með svokölluðu vistunarmati, eða færni- og heilsumati eins og pað kallast nú, hefur verið skilyrði fyrir flutningi einstaklinga í hjúkrunar- eða dvalarrými á Íslandi frá árinu 1990. ${ }^{8}$ Í lok desember 2007 tók gildi reglugerð par sem sett voru mun strangari skilyrði fyrir flutningi á hjúkrunarheimili en áður hafði verið. ${ }^{9}$ Fyrir pann tíma gátu stjórnir hjúkrunarheimila valið fólk inn á hjúkrunarheimilið, oft af löngum biðlistum, að pví skilyrði uppfylltu að viðkomandi ætti gilt vistunarmat. Pó var

\section{Á G R I P}

\section{INNGANGUR}

Fjölmargir pættir hafa áhrif á pjónustupörf og lifun íbúa hjúkrunarheimila, meðal annars inntökuskilyrði fyrir flutningi á hjúkrunarheimili. Markmið rannsóknarinnar var að athuga hvort munur væri á heilsufari, lifun og forspárgildi mismunandi heilsufars- og færnivísa fyrir eins og tveggja ára lifun peirra sem fluttu inn á íslensk hjúkrunarheimili á árunum 2003-2007 annars vegar og 2008-2014 hins vegar.

\section{EFNIVIĐUR OG ADFERĐIR}

Lýsandi, afturskyggn samanburðarrannsókn. Gögnin fengust úr gagnagrunni á vegum Embættis landlæknis yfir allar interRAl-matsgerðir á íslenskum hjúkrunarheimilum frá 1. janúar 2003 til og með 31. desember $2014(\mathrm{~N}=8.487)$.

\section{NIĐURSTÖĐUR}

Marktækur munur var á heilsu og lifun nýrra íbúa hjúkrunarheimila fyrir og eftir 31. desember 2007. Á seinna tímabilinu var meðalaldur 82,7 ár, en 82,1 ár á hinu fyrra og tíoni Alzheimer-sjúkdóms, blóðpurrðarsjúkdóms í hjarta, hjartabilunar, sykursýki og langvinnrar lungnateppu jókst. Eins árs lifun lækkaði úr 73,4\% i 66,5\% eftir 1. janúar 2008 og tveggja ára lifun úr 56,9\% i 49,1\%. Sterkustu áhættupættirnir fyrir dauðsfalli innan eins og tveggja ára frá komu á báđum tímabilum voru sjúkdómsgreiningarnar hjartabilun og langvinn lungnateppa, auk fleiri stiga á lífskvarðanum og langa ADL-kvarðanum.

\section{ÁLYKTUN}

Í kjölfar reglugerðarbreytingar 2007 voru peir sem fluttu á hjúkrunarheimili eldri og veikari við komu og lifðu skemur eftir vistaskiptin en peir sem fluttu inn fyrir breytingu. Niðurstöðurnar benda til að markmið reglugerðarbreytingarinnar, að forgangsraða peim sem voru veikastir, hafi pví náđst. Pví má telja líklegt aơ umönnunarpörf íbúa sé önnur og meiri en ádur.

kveðið á um að peir ættu að ganga fyrir sem beðið hefðu lengi og væru metnir með mjög brýna eða brýna pörf. Einnig að peir sem dveldu á sjúkrahúsi hefðu sama aðgengi og aðrir sem væru í pörf fyrir hjúkrunarrými. ${ }^{10}$ Með nýrri reglugerð varð pað hins vegar hlutverk vistunarmatsnefndar í viðeigandi heilbrigðisumdæmi að velja prjá einstaklinga sem töldust vera í mestri pörf með tilliti til pess hvort stigafjöldi úr vistunarmati var hár, hvort viðkomandi hefði legið lengur en 6 vikur á sjúkrahúsi eða beðið lengi í mikilli pörf fyrir vistun. ${ }^{9}$ Pannig gátu hjúkrunarheimili nú aðeins valið einn af pessum premur einstaklingum pegar rými losnaði, en áður gátu pau hugsanlega valið úr tugum nafna sem voru á biðlista. Pessi breyting var gerð til að forgangsraða peim einstaklingum sem voru í mestri pörf fyrir vistun og peim sem biðu á sjúkrahúsi, en um leið takmarkaðist valfrelsi hjúkrunarheimilanna. 
Tafla I. Samanburður á aldri, kyni, likamspyngdarstuðli og tíðni valinna sjúkdómsgreininga á milli tímabilanna 2003-2007 og 2008-2014. Međaltal og staðalfrávik fyrir aldur og líkamspyngdarstuðul, en fjöldi og hlutfall (\%) fyrir allt annað.

\begin{tabular}{|c|c|c|c|}
\hline & $\begin{array}{c}2003-2007 \\
n=1832\end{array}$ & $\begin{array}{c}2008-2014 \\
n=3397\end{array}$ & p-gildi* \\
\hline Aldur í árum & $82,1 \pm 7,7$ & $82,7 \pm 8,7$ & $<0,0001$ \\
\hline Líkamspyngdarstuðull & $24,0 \pm 6,0$ & $24,2 \pm 5,7$ & 0,3 \\
\hline Konur & $1070(58,4)$ & $1980(58,3)$ & 0,9 \\
\hline \multicolumn{4}{|c|}{ SJÚKDÓMSGREININGAR } \\
\hline Blóðpurrðarsjúkdómur í hjarta & $471(25,7)$ & $1046(30,8)$ & $<0,0001$ \\
\hline Hjartabilun & $336(18,3)$ & $756(22,3)$ & 0,0009 \\
\hline Sykursýki & $219(12,0)$ & $509(15,0)$ & 0,0025 \\
\hline Langvinn lungnateppa & $215(11,7)$ & $504(14,8)$ & 0,002 \\
\hline Alzheimer-sjúkdómur & $437(23,9)$ & $1005(29,6)$ & $<0,0001$ \\
\hline Önnur elliglöp & $583(31,8)$ & $1165(34,3)$ & 0,07 \\
\hline Astmi & $107(5,8)$ & $208(6,1)$ & 0,7 \\
\hline Helftarlömun & $133(7,3)$ & $221(6,5)$ & 0,3 \\
\hline Kvíði & $599(33,0)$ & $1185(34,9)$ & 0,1 \\
\hline Punglyndi & $683(37,3)$ & $1211(35,7)$ & 0,2 \\
\hline
\end{tabular}

*t-próf óháđra úrtaka fyrir aldur og líkamspyngdarstuðul, kí-kvaðratpróf fyrir tíðni sjúkdómsgreininga.

Ætla má að reglugerðarbreytingin sem gerð var 21. desember 2007 hafi haft áhrif á pann hóp sem dvaldi á íslenskum hjúkrunarheimilum frá og með árinu 2008, ${ }^{9}$ en áhrifin hafa ekki verið rannsökuð. Pekking á pörfum og lifun peirra sem flytja inn á hjúkrunarheimili er nauðsynleg til að hægt sé að skipuleggja viðeigandi pjónustu.

Markmið pessarar rannsóknar var að athuga hvort munur væri á heilsufari og færni peirra sem fluttu inn á íslensk hjúkrunarheimili á árunum 2003-2007 annars vegar og 2008-2014 hins vegar. Einnig að bera saman lifun íbúa á milli pessara tveggja tímabila og kanna hvaða forspárgildi mismunandi heilsufars- og færnivísar hefðu fyrir lifun til eins og tveggja ára.

\section{Efniviður og aðferðir}

Rannsóknin er lýsandi, afturskyggn samanburðarrannsókn. Gögn rannsóknarinnar eru niðurstöður matsgerða með mælitækinu „Gagnasafn um heilsufar og hjúkrunarpörf íbúa á öldrunarstofnunum" útgáfu 2.0 (Minimum Data Set 2.0), sem er gagnasöfnunarhluti matstækisins: „Raunverulegur aðbúnaður íbúa“ (Resident Assessment Instrument; interRAI). Á Íslandi hefur pessi gagnasöfnunarhluti matstækisins verið kallaður „RAImælitæki“ og verður vísað til pess heitis hér. RAI-mælitækið felur í sér samræmda skráningu og mat á heilsufari, færni og pörfum íbúa á hjúkrunarheimilum. Frá árinu 1996 hafa íbúar á íslenskum hjúkrunarheimilum verið metnir með RAI-mælitækinu og frá árinu 2003 hefur pað verið gert að minnsta kosti prisvar á ári og niðurstaða RAI-pyngdarstuðuls notuð til að reikna greiðslur til hjúkrunarheimila. ${ }^{11}$ RAI-mælitækið var fyrst og fremst hannað sem klínískt mælitæki (350 breytur) í peim tilgangi að bæta gæði
Tafla II. Samanburður á útkomu heilsu- og færnikvarðanna 6 milli tímabilanna 2003-2007 og 2008-2014. Meðaltal og stađalfrávik.

\begin{tabular}{lccccc}
\hline & $\begin{array}{c}2003-2007 \\
n=1832\end{array}$ & $\begin{array}{c}2008-2014 \\
n=3397\end{array}$ & p-gildi $^{*}$ \\
\hline Lífskvarði & 1,51 & $\pm 1,35$ & 1,87 & $\pm 1,40$ & $<0,0001$ \\
\hline Punglyndiskvarði & 1,85 & $\pm 2,33$ & 2,26 & $\pm 2,67$ & $<0,0001$ \\
\hline Vitrænn kvarði & 2,58 & $\pm 1,79$ & 3,0 & $\pm 1,74$ & $<0,0001$ \\
\hline Verkjakvarði & 1,18 & $\pm 0,97$ & 1,12 & $\pm 0,98$ & 0,046 \\
\hline Langur ADL-kvarði & 11,6 & $\pm 8,33$ & $15,37 \pm 8,25$ & $<0,0001$ \\
\hline Virknikvarði & 2,39 & $\pm 2,03$ & 2,54 & $\pm 1,97$ & 0,009 \\
\hline
\end{tabular}

*t-próf óháđra úrtaka. ADL: athafnir daglegs lífs.

umönnunar á hjúkrunarheimilum. Рað hefur pó einnig verið notað við gagnasöfnun fyrir rannsóknir víða um heim og sýnt hefur verið fram á réttmæti og áreiðanleika mælitækisins. ${ }^{12}$

Pverfaglegur hópur vinnur að gerð matsins á flestum hjúkrunarheimilum á Íslandi, en hjúkrunarfræðingur sem hefur lært á mælitækið hefur yfirumsjón með gerð matsins á hverjum stað. Upplýsinga fyrir matið er aflað úr sjúkraskrá, með athugun á íbúanum og viðtali við íbúa og ættingja hans, samkvæmt nákvæmri leiðbeiningabók RAI-mælitækisins sem skilgreinir hvernig meta á hvert atriði. Í pessari rannsókn eru notaðar valdar breytur úr RAImælitækinu auk útkomu úr eftirtöldum 6 heilsu- og færnikvörðum sem hannaðir hafa verið fyrir mælitækið.

Lifskvarðinn (Changes in Health, End-stage disease and Signs and Symptomsscale, CHESS scale), gefur til kynna hversu stöðugt heilsufar einstaklingsins er. Lægsta gildið er 0 og gefur til kynna að heilsufarið sé stöðugt en hæsta gildið 5 að heilsufar sé óstöðugt, hætta sé á andláti, sjúkrahússinnlögn og miklu álagi á umönnunaraðila. Rannsóknir hafa staðfest að kvarðinn hefur forspárgildi fyrir andláti. ${ }^{6,12}$

Verkjakvarðinn (Pain Scale), hefur lægsta gildi 0 sem merkir að einstaklingurinn hefur enga verki en hæsta gildið 3 að um mjög mikla og óbærilega verki sé að ræða. Rannsóknir benda til að kvarðinn sé áreiðanlegur til að meta verki hjá íbúum á hjúkrunarheimilum. ${ }^{13}$

Dunglyndiskvarðinn (Depression Rating Scale, DRS scale), hefur gildi frá 0 til 14. Gildið 0 gefur til kynna að einstaklingurinn hafi engin einkenni punglyndis. Gildi 3 bendir til vægs punglyndis og gildi 14 að um mjög alvarlegt punglyndi sé að ræða. ${ }^{14}$ Bent hefur verið á mjög gott næmi og viðunandi sérhæfni kvarðans en jafnframt að pörf sé á frekari rannsóknum á kvarðanum. ${ }^{14}$

Vitræni kvarðinn (Cognitive Performance Scale, CPS scale), hefur gildi 0-6. Gildið 0 pýðir að einstaklingurinn hefur óskerta vitræna getu en síðan stigversnandi vitræna getu með hækkandi gildum og gildi 6 gefur til kynna mjög mikla vitræna skerðingu. Sýnt hefur verið fram á ágæta fylgni pessa kvarða við MMSE (Mini-Mental State Examination) við mat á vitrænni getu. ${ }^{15}$

Langi ADL kvarðinn (ADL long scale), hefur gildi á bilinu 0 til 28. Hækkandi gildi bendir til versnandi færni einstaklingsins í athöfnum daglegs lífs (ADL). Rannsóknir hafa bent til að kvarðinn hafi ágætt næmi til að mæla breytingar á færni. ${ }^{12}$

Virknikvarðinn (Index of Social Engagement, ISE scale), gefur til kynna meiri virkni eftir pví sem talan er hærri og hefur gildi frá 


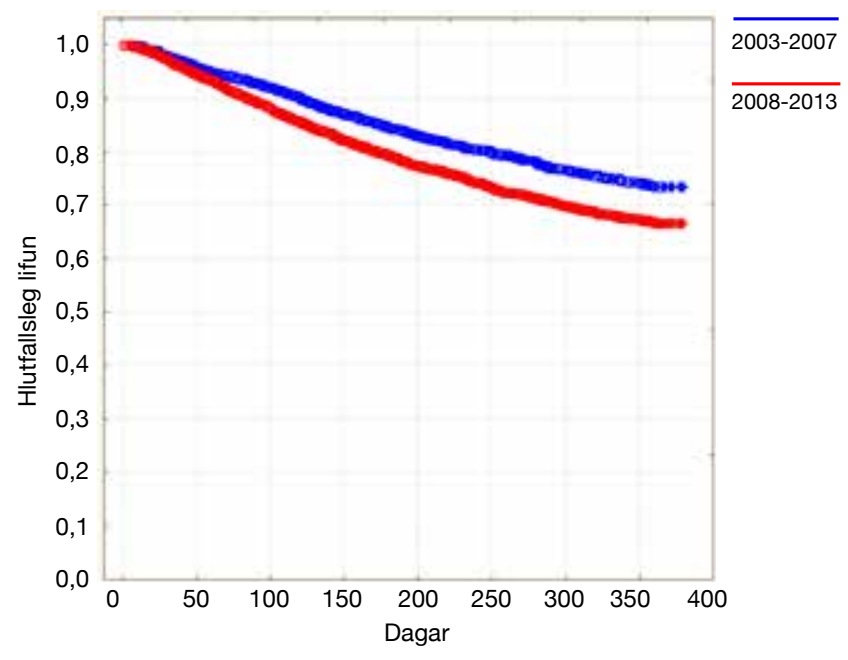

Mynd 1. Hlutfallsleg lifun (Kaplan-Meier) fyrsta árið eftir komu á hjúkrunarheimili. Blátt: Hópur 2003-2007 (n=1,832), 73,4\% lifun. Rautt: Hópur 2008-2013 (n=2895), $66,5 \%$ lifun $(p<0,0001)$.

0 til 6. Núll merkir að einstaklingurinn hefur dregið sig í hlé frá félagslegum samskiptum en hæsta gildið 6 gefur til kynna mikið frumkvæði og pátttöku í félagslegum athöfnum. Gildin 0-2 hafa verið tengd lítilli félagslegri virkni. ${ }^{16}$

\section{Úrtak}

Gögnin fengust úr miðlægum gagnagrunni á vegum Embættis landlæknis yfir allar RAI-matsgerðir á íslenskum hjúkrunarheimilum frá 1. janúar 2003 til og með 31. desember 2014 (N=8487). Ákveðið var að nota sambærilegan fjölda ára fyrir og eftir reglugerðarbreytinguna 21. desember 2007 til samanburðar. Ekki voru notuð eldri gögn en frá árinu 2003 vegna pess að pað ár jókst gerð RAI-mats á hjúkrunarheimilum vegna tengingar pess við greiðslur. ${ }^{3,11}$ Í pennan gagnabanka er dánardagur látinna íbúa einnig skráður, samkvæmt upplýsingum úr Pjóðskrá. Til pess að íbúi uppfyllti skilyrði úrtaks varð fyrsta RAI-mat hans að vera gert innan 6 mánaða frá flutningi inn á hjúkrunarheimili á ofannefndu tímabili (n=5229). Við lifunargreiningar var úrtakstímabilið takmarkað annars vegar við innflutning fyrir árslok 2012 (fyrir tveggja ára lifun), n=4173 og hins vegar árslok 2013 (eins árs lifun), $\mathrm{n}=4727$. Persónuvernd, vísindasiðanefnd og Embætti landlæknis veittu leyfi fyrir rannsókninni.

\section{Tölfræðileg úrvinnsla}

Notað var óparað Students t-próf og Mann-Whitney-U-próf til að reikna mun á milli hópa fyrir breytur á hlutfalls- og raðkvarða, ásamt kí-kvaðratprófi fyrir tvíkosta breytur. Munur á lifun milli tímabilanna fyrir og eftir 1 . janúar 2008 var fundinn með KaplanMeier-greiningu ásamt Cox F-prófi. Forspárgildi mismunandi áhættupátta var reiknað með fjölpátta áhættureiknilíkani (Cox Proportional Hazards Model), ásamt fjórum stýribreytum (aldri, kyni, líkamspyngdarstuðli (LPS) og hvaðan fólk kom), fyrst fyrir eina viðbótarbreytu í einu og síðan var gerð heildargreining allra

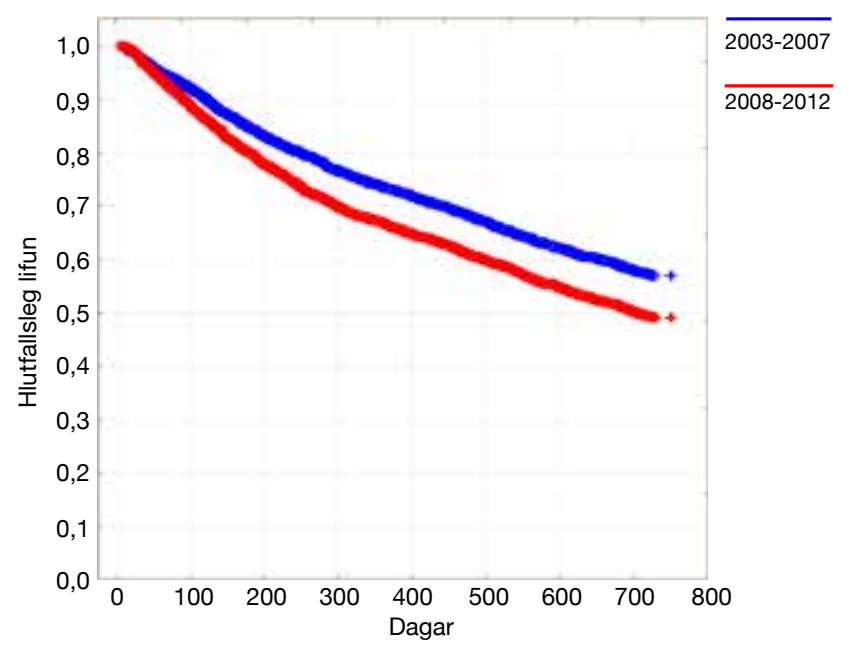

Mynd 2. Hlutfallsleg lifun (Kaplan-Meier) fyrstu tvö árin eftir komu á hjúkrunarheimili. Blátt: Hópur 2003-2007 (n=1.832), 56,9\% lifun. Rautt: Hópur 2008-2012 (n=2341), $49,1 \%$ lifun $(p<0,0001)$.

páttanna, innan hvors hóps fyrir sig, fyrir bæði eins árs og tveggja ára lifun. Marktektarmörk miðuðust við $p<0,05$. Gögnin voru greind með tölfræðiforritinu Statistica 12.

\section{Niðurstöður}

Á árunum 2003-2014 voru alls 5242 íbúar skráðir með komudag og fyrsta RAI-mat innan 6 mánaða frá komu, en 13 voru útilokaðir vegna skráningarvillu (dánardagur fyrir komudag). Samtals voru pví 5229 matsgerðir greindar í pessari rannsókn, 1832 fyrir tímabilið 2003-2007 og 3397 fyrir tímabilið 2008-2014. Meðalaldur íbúa í úrtakinu var hærri á síðara tímabilinu og einnig voru sjúkdómsgreiningarnar Alzheimer-sjúkdómur, blóðpurrðarsjúkdómur í hjarta, hjartabilun, sykursýki og langvinn lungnateppa tíðari pá en á fyrra tímabilinu, á meðan sjúkdómsgreiningarnar „önnur elliglöp“ (ekki Alzheimer-sjúkdómur), kvíði, punglyndi, astmi og helftarlömun voru jafntíðar á báđum tímabilunum, sjá töflu I. Hlutfall peirra sem komu frá eigin heimili (með eða án heimapjónustu) lækkaði úr 47,2\% á fyrra tímabilinu, i 39,2\% á hinu síðara $(\mathrm{p}<0,0001)$.

Munur reyndist á útkomu allra heilsu- og færnikvarða milli tímabilanna, sjá töflu II. Heilsufar íbúa mældist óstöðugra á tímabilinu 2008-2014 (lífskvarði), punglyndi var meira (punglyndiskvarði), vitræn geta var verri (vitrænn kvarði) og færni var verri (langur ADL-kvarði). Hins vegar voru verkir minni (verkjakvarði) og íbúarnir höfðu meira frumkvæði og gátu frekar tekið pátt í félagslegum athöfnum (virknikvarði).

Eins árs lifun nýinnfluttra á árunum 2003-2007 (n=1832) var borin saman við tímabilið 2008-2013 ( $\mathrm{n}=2895)$, sjá mynd 1. Alls voru $73,4 \%$ íbúa á lífi eftir eitt ár á fyrra tímabilinu, en $66,5 \%$ á hinu síðara $(\mathrm{p}<0,0001)$. Tveggja ára lifun fyrra tímabilsins var á sama hátt borin saman við tímabilið 2008-2012 (n=2341), sjá mynd 2. Alls voru $56,9 \%$ íbúa á lífi eftir tvö ár í fyrri hópnum, en $49,1 \%$ í hinum síðari $(\mathrm{p}<0,0001)$. 
Tafla III. Forspárstuðull fjögurra pekktra bakgrunnspátta (control variables), 9 sjúkdómsgreininga og 6 heilsu- og færnikvarða fyrir andláti innan árs međal íbúa á hjúkrunarheimili á árunum 2003-2007 og 2008-2013.

\begin{tabular}{|c|c|c|c|c|c|c|c|c|}
\hline & \multicolumn{4}{|c|}{ Hópur 2003-2007 (n=1832) } & \multicolumn{4}{|c|}{ Hópur 2008-2013 (n=2895) } \\
\hline & HR1a) & $95 \% \mathrm{Cl}$ & HR2b) & $95 \% \mathrm{Cl}$ & HR1a) & $95 \% \mathrm{Cl}$ & HR2b) & $95 \% \mathrm{Cl}$ \\
\hline Aldur & 1,03 & $1,02-1,05$ & 1,04 & $1,03-1,05$ & 1,02 & $1,01-1,03$ & 1,02 & $1,01-1,03$ \\
\hline Kyn (kona) & 0,58 & $0,48-0,69$ & 0,68 & $0,56-0,82$ & 0,66 & $0,58-0,75$ & 0,79 & $0,69-0,90$ \\
\hline Líkamspyngdarstuðull & 0,95 & $0,94-0,96$ & 0,96 & $0,95-0,97$ & 0,96 & $0,95-0,97$ & 0,96 & $0,95-0,97$ \\
\hline Kom frá sjúkrastofnun & 1,08 & $1,03-1,14$ & 1,02 & $0,97-1,07$ & 1,07 & $1,03-1,11$ & 1,02 & $0,98-1,06$ \\
\hline Alzheimer & 0,80 & $0,64-1,01$ & 0,64 & $0,49-0,82$ & 0,82 & $0,71-0,94$ & 0,72 & $0,61-0,85$ \\
\hline Önnur elliglöp & 0,98 & $0,81-1,19$ & 0,67 & $0,54-0,83$ & 1,10 & $0,96-1,25$ & 0,81 & $0,69-0,94$ \\
\hline Blóðpurrðarsjúkdómur í hjarta & 1,40 & $1,16-1,70$ & 1,39 & $1,13-1,70$ & 1,23 & $1,08-1,41$ & 1,05 & $0,91-1,21$ \\
\hline Hjartabilun & 1,55 & $1,26-1,91$ & 1,18 & $0,94-1,48$ & 1,82 & $1,58-2,09$ & 1,47 & $1,27-1,71$ \\
\hline Langvinn lungnateppa & 1,64 & $1,29-2,08$ & 1,38 & $1,07-1,79$ & 1,82 & $1,56-2,12$ & 1,30 & $1,11-1,54$ \\
\hline Astmi & 1,25 & $0,88-1,78$ & 1,05 & $0,72-1,54$ & 1,47 & $1,16-1,85$ & 1,07 & $0,84-1,37$ \\
\hline Sykursýki & 1,38 & $1,06-1,79$ & 1,38 & $1,05-1,82$ & 1,12 & $0,94-1,33$ & 1,03 & $0,88-1,26$ \\
\hline Helftarlömun & 0,97 & $0,68-1,37$ & 0,91 & $0,63-1,31$ & 0,81 & $0,62-1,07$ & 0,62 & $0,47-0,82$ \\
\hline Kvíði & 0,98 & $0,81-1,20$ & 0,87 & $0,67-1,01$ & 1,19 & $1,04-1,36$ & 1,02 & $0,89-1,17$ \\
\hline Punglyndi & 0,85 & $0,70-1,03$ & 0,76 & $0,62-0,94$ & 0,96 & $0,84-1,10$ & 0,78 & $0,68-0,90$ \\
\hline Lífskvarði & 1,65 & $1,55-1,76$ & 1,46 & $1,37-1,59$ & 1,66 & $1,58-1,74$ & 1,41 & $1,33-1,48$ \\
\hline Punglyndiskvarði & 1,07 & $1,03-1,11$ & 0,98 & $0,93-1,01$ & 1,05 & $1,03-1,07$ & 0,94 & $0,91-0,96$ \\
\hline Vitrænn kvarði & 1,12 & $1,07-1,18$ & 0,98 & $0,93-1,05$ & 1,19 & $1,14-1,24$ & 1,00 & $0,95-1,05$ \\
\hline Verkjakvarði & 1,37 & $1,25-1,51$ & 1,09 & $0,98-1,21$ & 1,41 & $1,32-1,50$ & 1,18 & $1,10-1,27$ \\
\hline Langur ADL-kvarði c) & 1,07 & $1,06-1,08$ & 1,04 & $1,02-1,05$ & 1,09 & $1,08-1,10$ & 1,06 & $1,05-1,07$ \\
\hline Virknikvarði & 0,80 & $0,78-0,86$ & 0,86 & $0,82-0,92$ & 0,80 & $0,77-0,83$ & 0,87 & $0,84-0,91$ \\
\hline
\end{tabular}

HR = forspárstuðull (Hazard Ratio). a): HR1 er einfaldur forspárstuðull, pað er pegar hver báttur sjúkdómsgreininga og kvarða var metinn einn i einu, ásamt efstu breytunum fjórum (stýribreytum). Tölugildin fyrir stýribreyturnar fjórar efst í dálki HR1 sýna niðurstöđuna pegar pær einar voru í módelinu. b): HR2 sýnir niðurstöðuna pegar allar breyturnar í dálkinum voru greindar saman. 95\% Cl: 95\% öryggisbil. c) ADL: athafnir daglegs lífs. Feitletraðar tölur sýna marktækan forspárstuðul fyrir andláti.

Forspárgildi hinna völdu sjúkdómsgreininga og heilsu- og færnikvarða er sýnt í töflu III fyrir eins árs lifun og í töflu IV fyrir tveggja ára lifun. Stýribreytur voru aldur, kyn, líkamspyngdarstuðull og hvaðan fólk flutti inn á hjúkrunarheimili. Töflurnar sýna að sjúkdómsgreiningarnar hjartabilun og langvinn lungnateppa voru sterkustu áhættupættirnir fyrir dauðsfalli í báðum hópunum, bæði innan eins og tveggja ára frá komu, ásamt blóðpurrðarsjúkdómi í hjarta, hin síðastnefnda pó einkum fyrir dauðsfalli innan tveggja ára (tafla IV). Sykursýki var einnig skýr áhættupáttur innan fyrri hópsins, en ekki eftir 2008, hvorki varðandi dauðsfall innan eins árs né tveggja ára. Minni líkur reyndust vera á dauðsfalli innan eins til tveggja ára frá komu ef einstaklingurinn var greindur með Alzheimer-sjúkdóm, einkum í síðari hópnum (frá og með 2008). Einnig virtist greiningin helftarlömun að vissu marki draga úr líkum á dauðsfalli í síðari hópnum og sjúkdómsgreiningin punglyndi dró einnig úr dánarlíkum í pessari greiningu, pó fyrst og fremst í sampættri greiningu allra pátta (töflur III og IV). Innan heilsu- og færnikvarðanna höfðu lífskvarðinn og langi ADL-kvarðinn skýrast forspárgildi, bæði fyrir eins og tveggja ára lifun í báđum hópum. Meiri félagsleg virkni (virknikvarði) var hins vegar jákvæð fyrir bæði eins og tveggja ára lifun. Við einföldu greininguna, pað er pegar einungis einni breytu var bætt við stýribreyturnar (HR1 í töflu III og IV), hvarf marktækni pess hvaðan fólk kom á hjúkrunarheimilið pegar ADLkvarðinn kom inn í greininguna og eingöngu pá.

\section{Umræður}

Niðurstöðurnar sýna að marktækur munur var á heilsu og lifun peirra sem fluttu á hjúkrunarheimili á árunum 2003-2007 annars vegar og hins vegar á tímabilinu 2008-2014. Peir sem fluttu á hjúkrunarheimili á seinna tímabilinu voru eldri og fleiri voru greindir með Alzheimer-sjúkdóm, blóðpurrðarsjúkdóm í hjarta, hjartabilun, sykursýki og langvinna lungnateppu. Færri fluttu á hjúkrunarheimili beint að heiman og hærra hlutfall lést innan eins og tveggja ára á seinna tímabilinu. Sterkustu áhættupættirnir fyrir dauðsfalli innan eins og tveggja ára frá komu á báðum tímabilum voru sjúkdómsgreiningarnar hjartabilun og langvinn lungnateppa, auk fleiri stiga á lífskvarðanum og langa ADL-kvarðanum.

Bent hefur verið á að tíðni mismunandi heilabilunarsjúkdóma og hegðunarbreytinga á hjúkrunarheimilum sé óljós, meðal annars vegna mismunandi greiningaraðferða. Í bandarískri rannsókn frá 2010 er áætlað að 32\% peirra sem eru 85 ára og eldri séu með Alzheimer-sjúkdóm, ${ }^{17}$ sem er hærra en í hópnum sem flutti á hjúkrunarheimili fyrir 2008 í pessari rannsókn, en svipað og í síðari hópnum. Hugsanlega skýrist pað af pví að meðalaldur ný- 
Tafla IV. Forspárstuðull fjögurra pekktra bakgrunnspátta, 9 sjúkdómsgreininga og 6 heilsu- og færnikvarða fyrir andláti innan tveggja ára međal nýbúa á hjúkrunarheimili á árunum 2003-2007 og 2008-2012.

\begin{tabular}{|c|c|c|c|c|c|c|c|c|}
\hline & \multicolumn{4}{|c|}{ Hópur 2003-2007 (n=1832) } & \multicolumn{4}{|c|}{ Hópur 2008-2013 (n=2341) } \\
\hline & HR1a) & $95 \% \mathrm{Cl}$ & $\mathrm{HR} 2 \mathrm{~b})$ & $95 \% \mathrm{Cl}$ & HR1a) & $95 \% \mathrm{Cl}$ & HR2b) & $95 \% \mathrm{Cl}$ \\
\hline Aldur & 1,03 & $1,02-1,04$ & 1,03 & $1,02-1,05$ & 1,03 & $1,02-1,03$ & 1,02 & $1,01-1,03$ \\
\hline Kyn (kona) & 0,64 & $0,55-0,74$ & 0,72 & $0,62-0,84$ & 0,65 & $0,58-0,72$ & 0,75 & $0,66-0,84$ \\
\hline Líkamspyngdarstuðull & 0,96 & $0,95-0,97$ & 0,96 & $0,95-0,97$ & 0,97 & $0,96-0,98$ & 0,97 & $0,96-0,98$ \\
\hline Kom frá sjúkrastofnun & 1,05 & $1,01-1,10$ & 1,00 & $0,96-1,04$ & 1,06 & $1,02-1,10$ & 1,00 & $0,97-1,04$ \\
\hline Alzheimer & 0,94 & $0,80-1,12$ & 0,81 & $0,66-0,98$ & 0,85 & $0,75-0,97$ & 0,78 & $0,67-0,91$ \\
\hline Önnur elliglöp & 1,12 & $0,96-1,29$ & 0,82 & $0,70-0,97$ & 1,16 & $1,03-1,31$ & 0,91 & $0,80-1,04$ \\
\hline Blóðpurrðarsjúkdómur í hjarta & 1,35 & $1,16-1,57$ & 1,30 & $1,10-1,52$ & 1,30 & $1,15-1,47$ & 1,15 & $1,02-1,31$ \\
\hline Hjartabilun & 1,61 & $1,37-1,90$ & 1,31 & $1,10-1,57$ & 1,74 & $1,53-1,98$ & 1,49 & $1,29-1,71$ \\
\hline Langvinn lungnateppa & 1,70 & $1,41-2,06$ & 1,45 & $1,18-1,79$ & 1,74 & $1,51-2,01$ & 1,27 & $1,09-1,49$ \\
\hline Astmi & 1,15 & $0,86-1,54$ & 0,91 & $0,67-1,24$ & 1,28 & $1,03-1,59$ & 0,96 & $0,77-1,21$ \\
\hline Sykursýki & 1,24 & $1,00-1,54$ & 1,27 & $1,02-1,58$ & 1,09 & $0,93-1,29$ & 1,04 & $0,88-1,23$ \\
\hline Helftarlömun & 0,96 & $0,73-1,27$ & 0,87 & $0,65-1,17$ & 0,89 & $0,70-1,13$ & 0,70 & $0,55-0,90$ \\
\hline Kvíði & 1,06 & $0,91-1,23$ & 0,97 & $0,82-1,14$ & 1,12 & $0,99-1,27$ & 1,00 & $0,88-1,14$ \\
\hline Punglyndi & 0,85 & $0,73-0,99$ & 0,74 & $0,63-0,87$ & 1,03 & $0,92-1,16$ & 0,85 & $0,75-0,97$ \\
\hline Lífskvarði & 1,52 & $1,44-1,61$ & 1,34 & $1,26-1,43$ & 1,47 & $1,41-1,53$ & 1,28 & $1,22-1,35$ \\
\hline Punglyndiskvarði & 1,07 & $1,04-1,10$ & 1,00 & $0,96-1,02$ & 1,06 & $1,04-1,08$ & 0,98 & $0,95-0,99$ \\
\hline Vitrænn kvarði & 1,13 & $1,09-1,18$ & 1,00 & $0,94-1,04$ & 1,15 & $1,11-1,19$ & 1,00 & $0,95-1,04$ \\
\hline Verkjakvarði & 1,26 & $1,17-1,36$ & 1,06 & $0,98-1,15$ & 1,26 & $1,19-1,34$ & 1,12 & $1,05-1,19$ \\
\hline Langur ADL-kvarði c) & 1,06 & $1,05-1,07$ & 1,03 & $1,02-1,04$ & 1,06 & $1,06-1,07$ & 1,05 & $1,04-1,05$ \\
\hline Virknikvarði & 0,83 & $0,80-0,86$ & 0,87 & $0,83-0,92$ & 0,83 & $0,81-0,86$ & 0,90 & $0,87-0,94$ \\
\hline
\end{tabular}

HR = forspárstuðull (Hazard Ratio). a): HR1 er einfaldur forspárstuðull, p.e. pegar hver páttur sjúkdómsgreininga og kvarða var metinn einn í einu, ásamt efstu breytunum fjórum (stýribreytum). Tölugildin fyrir stýribreyturnar fjórar í dálki HR1 sýna niðurstöðuna pegar pær einar voru í módelinu. b): HR2 sýnir niðurstöðuna pegar allar breyturnar í dálkinum voru greindar saman. $95 \% \mathrm{Cl}$ : 95\% öryggisbil. c) ADL: athafnir daglegs lífs. Feitletraðar tölur sýna marktækan forspárstuðul fyrir andláti.

innfluttra á íslenskum hjúkrunarheimilum er lægri en 85 ár og hærri aldur nýinnfluttra á síðara tímabilinu gæti pví einnig skýrt aukna tíðni Alzheimer-sjúkdóms í peim hópi. Sjúkdómsgreiningin hjartabilun var einnig algengari á seinna tímabilinu og nokkru algengari en í nýlegri bandarískri rannsókni, en par var hlutfallið 18,7-19,5\%. ${ }^{18}$ Sjúkdómsgreiningin blóðpurrðarsjúkdómur í hjarta var algengari á síðara tímabilinu og jafnframt algengari en í evrópskri rannsókn par sem hlutfallið var 25,3\%. ${ }^{19}$ Niðurstöðurnar gefa pví vísbendingar um að hópurinn sem flutti á hjúkrunarheimili eftir desember 2007 sé veikari en á fyrra tímabilinu út frá peim sjúkdómsgreiningum sem skráðar eru. Pó er ekki hægt að útiloka að nákvæmari skráning sjúkdómsgreininga gæti haft einhver áhrif.

Hlutfall peirra sem voru greindir með langvinna lungnateppu (LLT) var hærra seinna tímabilið en pó nokkuð lægra en 21,5\%, sem er hlutfall peirra sem eru með LLT á bandarískum hjúkunarheimilum. ${ }^{20}$ Hlutfallsleg aukning LLT skýrist líklega annars vegar af fleiri öldruðum með langa reykingasögu og hins vegar af bættri greiningu LLT á síðari árum, en pó er athyglisvert að astmagreiningum fækkar ekki á móti. Aukning á sykursýki á milli tímabila kemur ekki á óvart, en íslensk rannsókn hefur áđur sýnt sömu próun. ${ }^{21}$ Kerfisbundið yfirlit Garcia og Brown sýndi rannsóknarniðurstöður par sem tíðni sykursýki á hjúkrunarheimilum var bæði lægri og hærri tíðni (8,4\%-53\%) en í pessari rannsókn. ${ }^{22}$ Aukin tíðni ofangreindra sjúkdóma eykur umönnunarbyrði og pörf fyrir faglært starfsfólk á hjúkrunarheimilunum.

Hlutfall peirra sem dóu innan eins árs (26,6\%) eða tveggja ára $(43,1 \%)$ á fyrra tímabili pessarar rannsóknar er sambærilegt við áður birtar niðurstöður frá tímabilinu 1995-2006, enda skarast pessi tímabil að hluta. ${ }^{6}$ Hins vegar hafði petta hlutfall hækkað marktækt eftir desember 2007 (1 ár: 33,5\%; 2 ár: 50,9\%). Pað er pví ljóst að verulegar breytingar urðu á lifun nýinnfluttra á íslenskum hjúkrunarheimilum eftir desember 2007. Auk breytinga á reglugerð geta fleiri pættir hafa haft áhrif á lifun sem erfitt er að fastsetja í pessari rannsókn, en pað eru framboð á hjúkrunarheimilisrýmum, fækkun dvalarrýma og lokun líknardeildar á Landakoti.

Niðurstöðurnar sýna hærra hlutfall peirra sem létust innan eins og tveggja ára borið saman við erlendar rannsóknir. Í rannsókn 7 Evrópulanda ( $\mathrm{N}=3036 ; 57$ hjúkrunarheimili) létust 20\% íbúa innan árs ${ }^{23}$ og í bandarískri rannsókn sem skoðaði interRAI-gögn 1.217.008 íbúa á hjúkrunarheimilum létust $24 \%$ innan árs og $35 \%$ innan tveggja ára. ${ }^{18}$ Ennfremur sýndi sænsk rannsókn (n=333) par sem skoðuð var dánartíðni íbúa sem fluttu á hjúkrunarheimili á tímabilinu 2007-2011 að 44\% íbúa höfðu látist innan priggja ára frá flutningi. ${ }^{24}$ Í ofangreindum samanburði parf pó að hafa í huga að margt er ólíkt í heilbrigðiskerfi og rekstri hjúkrunarheimila peirra 
landa sem verið er að bera saman, sem og í úrtaki og aðferðafræði pessara rannsókna. Ofangreindur samanburður vekur pó pá hugsun hvort aldraðir Íslendingar purfi að bíða of lengi áður en peir fá rými á hjúkrunarheimili og skilyrði fyrir dvöl á hjúkrunarheimili pví hugsanlega orðin of ströng eftir reglugerðarbreytingu í desember 2007. Ástæða væri til að skoða aðstæður peirra sem búa heima og bíða eftir flutningi á hjúkrunarheimili.

Sjúkdómsgreiningarnar hjartabilun og langvinn lungnateppa voru sterkustu áhættupættirnir fyrir dauðsfalli í báðum hópunum, bæði innan eins og tveggja ára frá komu, ásamt blóðpurrðarsjúkdómi í hjarta, hin síðastnefnda pó einkum fyrir dauðsfalli innan tveggja ára. Erlendar rannsóknir sýna svipaðar niðurstöður. ${ }^{1,2}$

Athyglisvert er að sykursýki var skýr áhættupáttur fyrir andláti á tímabilinu 2003-2007 en ekki eftir 2008. Rímar sú niðurstaða við erlendar rannsóknir. ${ }^{2,7}$ Bent hefur verið á að gott eftirlit með sykursýkinni geti verið verndandi páttur til að seinka dauðsföllum. ${ }^{25}$ Rannsókn sem gerð var á íslenskum og norskum hjúkrunarheimilum á árunum 2011-2015 fann að sjúkdómsgreiningin sykursýki var skráð hjá fleiri íbúum en peim sem voru á blóðsykurslækkandi lyfjum á Íslandi en bara hjá 75\% sama hóps í Noregi. ${ }^{26}$ Pað að íbúi hafi ekki réttar sjúkdómsgreiningar eykur líkur á mistökum í umönnun. Ennfremur sýndi íslensk rannsókn að íbúar á hjúkrunarheimilum sem voru með sykursýki höfðu fleiri vandamál sem vitað er að tengjast seinkvillum sykursýki, en aðrir íbúar, svo sem hjartasjúkdóma, nýrnabilun og prýstingssár á alvarlegum stigum, sem allt krefst viðeigandi meðferðar og eftirlits. ${ }^{21}$

Athygli vekur að allir heilsu- og færnikvarðar sýndu mun milli tímabilanna, par sem vitræn og líkamleg geta versnaði á seinna tímabilinu. Hins vegar vekur athygli að verkjakvarðinn og virknikvarðinn sýndu betri útkomu á seinna tímabilinu, sem gæti tengst aukinni áherslu á verkjameðferð og aukinni afpreyingu á hjúkrunarheimilunum. Hér höfðu lífskvarðinn og langi ADLkvarðinn skýrasta forspárgildið fyrir andláti. Fjölmargar rannsóknir hafa sýnt fram á forspárgildi ADL-færni fyrir andláti ${ }^{2,6,27}$ og rannsókn sýndi fram á forspárgildi lífskvarðans, langa ADLkvarðans og vitræna kvarðans fyrir andláti. ${ }^{1}$

Pegar strangari skilyrði eru sett fyrir flutningi á hjúkrunarheimili má búast við að heilsufar íbúa sé lakara við komu en áður. Jafnframt skemmri dvalartíma parf að hafa í huga að vaxandi fjölda aldraðra sem dvelur á hjúkrunarheimilum deyr par en ekki á sjúkrahúsi. ${ }^{28}$ Skammur dvalartími og vaxandi fjöldi einstaklinga sem deyr á hjúkrunarheimilum er áminning um að mikil pörf er á pekkingu á líknandi meðferð og lífslokameðferð á hjúkrunarheimilum. Pá hefur íslensk rannsókn sýnt að einkennameðferð geti verið ábótavant á hjúkrunarheimilum og pörf fyrir líknandi meðferð sé mikil..$^{29}$ Með breyttu heilsufari íbúa og par með breyttri umönnunarpörf er ljóst að starfsfólk parf að hafa viðeigandi pekkingu og möguleika á að mæta pörfum íbúanna. ${ }^{2}$ Slíkar breytingar gætu falið í sér pörf fyrir fleiri starfsmenn (fleiri veittar hjúkrunarklukkustundir) og hærra hlutfall fagfólks og par með aukið fjármagn til reksturs hjúkrunarheimila.

Styrkur rannsóknarinnar felst í pví að gögnin ná yfir 12 ára tímabil og borin eru saman annars vegar gögn fyrir 5 ár (20032007) fyrir breytingu á reglugerð og hins vegar allt að 7 ár (20082014) eftir breytingu. Tímabilið eftir breytinguna er pví nægilega langt til að áhrifa hennar sé farið að gæta að fullu. ó verður að telja pað til galla að um klínísk gögn er að ræða en ekki rannsóknargögn, sem getur skert áreiðanleika gagnanna. Einnig má teljast galli að ekki hefur farið fram formleg rannsókn á áreiðanleika í gerð matsins á Íslandi. Pó hefur verið bent á að með klínískum gögnum er hægt að fá langtímagögn og að gögn sem fengin eru með interRAI-mælitækinu eru mikilvæg rannsóknargögn. ${ }^{30}$ Jafnframt hefur verið bent á að áreiðanleiki mælitækisins hefur reynst vera í meðallagi til mikill í rannsóknum. ${ }^{12}$

\section{Ályktun}

Eftir breytingar á vistunarmati frá og með 2008 eru peir sem flytja á hjúkrunarheimili marktækt eldri og veikari en á árunum fyrir 2008 og lifun eftir vistaskiptin er skemmri en áður. Hlutfall peirra sem komu frá eigin heimili en ekki stofnun eða sjúkrahúsi lækkaði á síðara tímabilinu. Fólk kemst pví ekki á hjúkrunarheimili fyrr en pað er orðið verulega veikt og pví hugsanlegt að ákveðinn hópur sem parf á hjúkrunarheimilispjónustu að halda bíði of lengi eftir slíkri pjónustu. Markmið reglugerðarbreytingarinnar, að forgangsraða peim sem voru veikastir hefur pví náðst, en veikari íbúar kalla á aðra og meiri umönnun en áður.

\section{Pakkir}

Rannsakendur vilja pakka styrk til rannsóknarinnar frá vísindasjóði Landspítala og vísindasjóði Félags íslenskra hjúkrunarfræðinga.

\section{Heimildir}

1. Lee JS, Chau PP, Hui E, Chan F, Woo J. Survival prediction in nursing home residents using the Minimum Data Set subscales: ADL Self-Performance Hierarchy, Cognitive Performance and the Changes in Health, End-stage disease and Symptoms and Signs scales. Eur J Public Health 2009; 19: 308-12.

2. Sund Levander M, Milberg A, Rodhe N, Tingström P, Grodzinsky E. Differences in predictors of 5-year survival over a 10-year period in two cohorts of elderly nursing home residents in Sweden. Scand J Caring Sci 2016; 30:7 14-20.

3. Hjaltadóttir I, Hallberg IR, Ekwall AK, Nyberg P. Health status and functional profile at admission of nursing home residents in Iceland over 11-year period. Int J Older People Nurs 2012; 7: 177-87.
4. Kelly A, Conell-Price J, Covinsky K, Cenzer IS, Chang A, Boscardin WJ, et al. Length of stay for older adults residing in nursing homes at the end of life. J Am Geriatr Soc 2010; 58:1 701-6.

5. Porock D, Parker Oliver D, Zweig S, Rantz M, Mehr D, Madsen R, et al. Predicting death in the nursing home: development and validation of the 6-month Minimum Data Set mortality risk index. J Gerontol A Biol Sci Med Sci 2005; 60: 491-8.

6. Hjaltadóttir I, Hallberg IR, Ekwall AK, Nyberg P. Predicting mortality of residents at admission to nursing home: a longitudinal cohort study. BMC Health Serv Res 2011; $11: 86$.
7. Shah SM, Carey IM, Harris T, DeWilde S, Cook DG Mortality in older care home residents in England and Wales. Age Ageing 2013; 42: 209-15.

8. Jónsson PV, Björnsson S. Mat á vistunarpörf aldraðra. Læknablaðið 1991; 77: 313-7.

9. Heilbrigðis- og tryggingamálaráðuneytið. Reglugerð um vistunarmat no. 1262/2007.

10. Heilbrigðis- og tryggingamálaráðuneytið. Reglugerð um pjónustuhóp aldraðra og vistunarmat aldraðra no. 791/2001.

11. Embætti landlæknis. Heildrænt hjúkrunarheimilismat. 2019. 
12. Mor $\mathrm{V}$, Intrator $\mathrm{O}$, Unruh MA, Cai S. Temporal and geographic variation in the validity and internal consistency of the Nursing Home Resident Assessment Minimum Data Set 2.0. BMC Health Serv Res 2011; 11: 78.

13. Fries BE, Simon SE, Morris JN, Flodstrom C, Bookstein FL. Pain in US nursing homes: validating a pain scale for the minimum data set. Gerontologist 2001; 41: 173-9.

14. Burrows AB, Morris JN, Simon SE, Hirdes JP, Phillips C Development of a minimum data set-based depression rating scale for use in nursing homes. Age Ageing 2000; 29: 165-72.

15. Gruber-Baldini AL, Zimmerman SI, Mortimore E Magaziner J. The validity of the minimum data set in measuring the cognitive impairment of persons admitted to nursing homes. J Am Geriatr Soc 2000; 48: 1601-6.

16. Resnick HE, Fries BE, Verbrugge LM. Windows to their world: the effect of sensory impairments on social engagement and activity time in nursing home residents. J Gerontol B Psychol Sci Soc Sci 1997; 52: S135-S44.

17. Hebert LE, Weuve J, Scherr PA, Evans DA. Alzheimer disease in the United States (2010-2050) estimated using the 2010 census. Neurology 2013; 80: 1778-83.

18. Ogarek JA, McCreedy EM, Thomas KS, Teno JM, Gozalo PL. Minimum Data Set Changes in Health, End-Stage Disease and Symptoms and Signs Scale: A Revised Measure to Predict Mortality in Nursing Home Residents. J Am Geriatr Soc 2018; 66: 976-81
19. Foebel AD, Liperoti R, Gambassi G, Gindin J, Ben Israel J, Bernabei $\mathrm{R}$, et al. Prevalence and correlates of cardiovascular medication use among nursing home residents with ischemic heart disease: results from the SHELTER study. J Am Med Dir Assoc 2014; 15: 410-5.

20. Zarowitz BJ, O'Shea T. Chronic obstructive pulmonary disease: prevalence, characteristics, and pharmacologic treatment in nursing home residents with cognitive impairment. J Manag Care Pharm 2012; 18: 598-606.

21. Hjaltadóttir I, Sigurðardóttir Á. Algengi sykursýki og heilsufar íbúa á íslenskum hjúkrunarheimilum 2003-2012. Læknablaðið 2015; 101: 79-84.

22. Garcia TJ, Brown SA. Diabetes management in the nursing home. Diabetes Educ 2011; 37: 167-87.

23. Vetrano DL, Collamati A, Magnavita $\mathrm{N}$, Sowa $\mathrm{A}$ Topinkova E, Finne-Soveri $\mathrm{H}$, et al. Health determinants and survival in nursing home residents in Europe: Results from the SHELTER study. Maturitas 2018; 107: 19-25.

24. Samefors M, Östgren CJ, Mölstad S, Lannering C, Midlöv $\mathrm{P}$, Tengblad A. Vitamin D deficiency in elderly people in Swedish nursing homes is associated with increased mortality. Eur J Endocrinol 2014; 170: 667-75.

25. Rawshani A, Rawshani A, Franzén S, Sattar N, Eliasson $B$, Svensson AM, et al. Risk factors, mortality, and cardiovascular outcomes in patients with type 2 diabetes. N Engl J Med 2018; 379: 633-44.
26. Haugstvedt A, Graue M, Aarflot M, et al. Challenges in maintaining satisfactory documentation routines and evidence-based diabetes management in nursing homes. Int Diabet Nurs 2016; 13: 37-42.

27. Vossius C, Selbæk G, Benth JŠ, Bergh S. Mortality in nursing home residents: A longitudinal study over three years. PloS one 2018; 13: e0203480.

28. Jónsson Á, Bernhöft I, Bernhardsson K, Jónsson PV. Afturvirk rannsókn á heilsufarsbreytum heimilismanna á Droplaugarstöðum árin 1983-2002. Læknablaðið 2005; 91: 153-60.

29. Eiríksdóttir JÓ, Bragadóttir H, Hjaltadóttir I. Samanburður á heilsufari, færni, einkennum og meðferðarmarkmiðum íbúa á íslenskum hjúkrunarheimilum eftir áætluðum lífslíkum. Tímarit hjúkrunarfræðinga 2017; 93: 79-85.

30. Shin JH, Scherer Y. Advantages and disadvantages of using MDS data in nursing research. J Gerontol Nurs 2009; 35: 7-17.

\section{Health and survival in Icelandic nursing homes 2003 - 2014, before and after the setting of stricter criteria for nursing home admission in December 2007}

\author{
Ingibjörg Hjaltadóttir ${ }^{1,2}$ \\ Kjartan Ólafsson ${ }^{3}$ \\ Árún K. Sigurðardóttir ${ }^{4,5}$ \\ Ragnheiður Harpa Arnardóttir $4,6,7$
}

Introduction: Many factors influence the nursing needs and survival of nursing home residents, including the admission criteria. The aim of the study was to compare health, survival and predictors for one- and two-year survival of people entering Icelandic nursing homes between 2003-2007 and 2008-2014.

Material and methods: Retrospective, descriptive, comparative study. The data was obtained from a Directorate of Health database for all interRAl assessments of Icelandic nursing homes from January 1, 2003, to December 31, 2014 ( $N=8487$ ).

Results: There was a significant difference in the health and survival of new nursing home residents before and after December 31, 2007. In the latter period, the mean age was 82.7 years. In the previous period, it was 82.1 years, and the prevalence of Alzheimer's disease, ischemic heart disease, heart failure, diabetes and COPD increased between the periods. One-year survival decreased from $73.4 \%$ to $66.5 \%$, and two-year survival decreased from $56.9 \%$ to $49.1 \%$. The strongest mortality risk factors were heart failure and chronic obstructive pulmonary disease, as well as high scores on the CHESS scale and ADL long scale.

Conclusion: After 2007, new residents were older, in poorer health, and their life expectancy was shorter than for those moving to nursing homes before that. The results suggest that the aim of the regulatory change was achieved, i.e., to prioritise those in worst health. Their care needs may therefore be different and greater than before.

${ }^{1}$ Faculty of Nursing, University of Iceland, ${ }^{2}$ Emergency, Geriatrics, Rehabilitation Services, National University Hospital, ${ }^{3}$ School of Humanities and Social Sciences, University of Akureyri, ${ }^{4}$ Department of Education and Science, Akureyri Hospital, ${ }^{5}$ Department of Rehabilitation, Akureyri Hospital, ${ }^{6}$ Respiratory-, allergy- and sleep research, Faculty of Medicine, Uppsala University, Sweden.

Key words: Geriatrics, Minimum Data Set, nursing homes, old people, elderly people, survival. 